\title{
Stepping Into the Same River Twice? Judicial Independence in Old and New Authoritarianism
}

\author{
Zoltán Szente ${ }^{1}$ \\ ${ }^{1}$ Institute for Legal Studies at the Centre for Social Sciences and Department of Constitutional and Comparative Public Law, \\ National University of Public Service, Budapest, Hungary \\ Corresponding author: szente.zoltan@tk.mta.hu
}

(Received 12 September 2021; accepted 29 September 2021)

\begin{abstract}
The study seeks to answer the question of whether there are similarities between the methods used to limit judicial independence in Hungary during the last phase of the communist regime, i.e. before the democratic transition, and today, when many scholars believe that an authoritarian transition is taking place in this country. For this purpose, I argue that despite the undeniable fundamental differences between the political and legal system of these two periods, the mechanisms and ways as the independence of judiciary were and are influenced by the government can plausibly be compared. The analysis seems to support this presumption: both the formal instruments and the informal channels of influence in the hands of the ruling political forces show a number of similarities. Thus, even if there are differences in the degree of their application and result, from centralizing the system of judicial administration to replacing court leaders with politically loyal people there are a number of instruments that enable central government to influence the judiciary, while maintaining the appearance of judicial independence.
\end{abstract}

Keywords: Judiciary; judicial independence; late Kádár era; authoritarianism; Hungary

\section{A. Introduction}

According to some studies, even decades after the collapse of the communist regime, certain features of the socialist past can be found in the Hungarian legal system. ${ }^{1}$ These are not only certain remnants of substantive law, but are deeply entrenched in legal culture, such as state paternalism, ${ }^{2}$ or the dominant role of textual interpretation of the law in judicial practice. ${ }^{3}$

Other studies have shown that in Hungary, the main features of contemporary authoritarian transition of the constitutional and political system, like the centralization of power, the capture of

Zoltán Szente, Professor of Law, National University of Public Service, Department of Constitutional Law and Research Professor, Centre for Social Sciences, Institute for Legal Studies, Budapest, szente.zoltan@tk.mta.hu. The work was supported also by 129018 program on Resilience of the Hungarian legal system funded by the National Research Development and Innovation Office.

${ }^{1}$ András Jakab \& Miklós Hollán, Die dogmatische Hinterlassenschaft des Sozialismus im heutigen Recht: Das Beispiel Ungarn, 46 JAHRBUCH FÜR OSTRECHT 11-40 (2005).

${ }^{2}$ Herbert Küpper, A szocialista maradványok szerepe a magyar alkotmányban [The Role of Socialist Remnants in the Hungarian Constitution], 11 Fundamentum 53-60 (2007) (Hung.).

${ }^{3}$ Pokol Béla, Felsöbírósági jogértelmezés Magyarországon [Legal Interpretation of High Courts in Hungary], 54 JOGTUDOMÁNYI KÖZLÖNY 493-98 (1999) (Hung.).

(C) The Author(s), 2021. Published by Cambridge University Press on behalf of the German Law Journal. This is an Open Access article, distributed under the terms of the Creative Commons Attribution licence (https://creativecommons.org/licenses/by/4.0/), which permits unrestricted re-use, distribution, and reproduction in any medium, provided the original work is properly cited. 
public institutions, and the abolition or restriction of the autonomy of independent control bodies threaten judicial independence. ${ }^{4}$

If we combine the findings of these scholarly writings, it is a rational question whether the restriction of judicial independence has been accomplished through similar methods and mechanisms as under the socialist era before the system change.

In this regard, opposing hypotheses can be formulated. First, it can be presumed that these two periods are not comparable to each other even if we focus on the late Kádár era, which was a soft authoritarian regime. In fact, Hungarian socialism was a Soviet-type "real" autocracy in the sphere of influence of the Soviet Union, while today, at most, an emerging authoritarian system can only be talked about in a country which is a member of the European Union within the framework of a more or less Western-like constitutional system.

The opposing hypothesis is that whatever differences there are between these two periods, it is reasonable to assume that similar means are used to achieve similar goals within a closed institutional system, especially if we consider that the late Kádár era was only a moderate authoritarian regime where the judicial independence was more or less recognized and realized.

This Article proceeds as follows. Section B argues that despite all the differences, the current state of the judiciary is comparable to that of the late Kádár era. Section C shows what formal and informal means were used in the past and are used today to limit judicial independence, while Section D summarizes the conclusions that can be drawn from the comparison.

\section{B. In Defense of Comparing Socialist and Contemporary Judiciary}

No doubt, it can be irritating to compare the judicial system of the late socialism with the situation of contemporary judiciary, as the courts before the democratic transition in 1989-1990 were one of the institutional backbones of a soft dictatorship under the tutelage of the Warsaw Pact, whereas today the independence of the judiciary is guaranteed by a more or less Western-type constitution and membership within the European Union.

In fact, there is a strict limitation of comparability of these periods. In the wider context, Hungary was a socialist authoritarian regime based on the exclusive political power of the communist party ${ }^{5}$ before $1989,{ }^{6}$ while today there is a pluralist political system. The constitutional context and political environment are very different. In the socialist era, the basic constitutional principle was the unity of public power, ${ }^{7}$ whereas the contemporary constitutional system, even in its "illiberal" 8 or "populist" form, is based on the principle of separation of powers.

\footnotetext{
${ }^{4}$ See, e.g., KIM LANE SCHePpele, Understanding Hungary's Constitutional Revolution, in CONSTITUTIONAL CRISIS IN THE European Constitutional Area: Theory, Law and Politics in Hungary and Romania 111-24 (Armin von Bogdandy \& Pál Sonnevend eds., 2015); Daniel Kelemen, Europe's Other Democratic Deficit: National Authoritarianism in Europe's Democratic Union, 52 Gov't And Opposition 211-38 (2017); Matthijs Bogaards, De-democratization in Hungary: Diffusely Defective Democracy, 25 Democratization 1481-99 (2018).

${ }^{5}$ Hungarian Socialist Worker's Party.

${ }^{6}$ See, e.g., Lajos IzSÁK, A Political History of Hungary 1944-1990 (2002).

${ }^{7}$ Formally, the communist constitutionalism was based on parliamentary sovereignty. See MAGYARORSZÁG ALAPTÖRVÉNYE [The Fundamental Law of Hungary], AlaptörvénY, art. 26, $\$ 1$ (“The National Assembly exercises all rights issuing from the sovereignty of the people.").

${ }^{8}$ See, e.g., Marc F. Plattner, Illiberal Democracy and the Struggle on the Right, 30 J. DEMOCRACY 9-10 (2019); Tímea Drinóczi \& Agnieszka Kacała, Illiberal Constitutionalism: The Case of Hungary and Poland, 20 German L. J. 1140-66 (2019). It is worth noting that Prime Minister Viktor Orbán himself characterized the political changes as aiming at an illiberal regime in a speech in 2014. See "The New State that we are Constructing in Hungary is an Illiberal State, a non-liberal state," https:// index.hu/belfold/2014/07/29/ez_orban_uj_allamidealja/ (accessed Nov. 17, 2020).

${ }^{9}$ See, e.g., Luigi Corrias, Populism in a Constitutional Key: Contstituent Power, Popular Sovereignty and Constitutional Identity, 12 Eur. Const. L. Rev. 10, 19, 22 (2016); Bojan Bugaric, Could Populism be Good for Constitutional Democracy?, 15 AnN. Rev. Law \& Soc. ScI. 45 (2019); Paul Blokker, Varieties of Populist Constitutionalism: The Transnational Dimension, 20 GERMAN L. J. 340 (2019).
} 
As to the judicial system, while during the socialist regime membership of the state party was unquestionably a prerequisite for filling higher positions, ${ }^{10}$ today, the political commitment of judges as well as their party membership are prohibited by the Constitution. ${ }^{11}$ At the moment, there is a four-tier judicial organizational system, instead of the three-level judiciary of the socialist period. While all judges were formally elected during the communist era, ${ }^{12}$ they are appointed today by the head of state. ${ }^{13}$ Under socialism, the central administration of judiciary was managed by the Minister of Justice, ${ }^{14}$ whereas nowadays a formally self-government system of administration is working. ${ }^{15}$

Beyond the fundamental differences between the political and legal systems of these two periods, we can find surprising similarities too. If we take for granted that since 2010 an authoritarian transition has been taking place in Hungary, ${ }^{16}$ the tools used by the old and the new authoritarian governments are plausibly comparable to each other, even if they represent two different forms and degrees of authoritarianism. But even in this case, any comparison can be rationally made only between the so-called late Kádár era ${ }^{17}$ in the 1980 s as a soft authoritarian period of socialism, and the past decade since 2010, depicting them as epochs of a declining and a developing authoritarianism, respectively.

Regarding the similarities of judicial systems of the two eras, it is worth stressing that the judicial reform of 1972 emphasized the principle of a unified court system which means the judicial monopoly of justice. ${ }^{18}$ From that time, extra-judicial bodies-administrative authorities in cases of minor offenses, arbitration courts, public guardianship authorities - could adjudicate in legal disputes only exceptionally, just like today. There were some special courts after 1972 when economic and labor disputes were taken away from quasi-judicial bodies and were conferred to labor courts. ${ }^{19}$ Besides those special courts, military courts operated just like today. As a major rule, courts adjudicated in first instance in panels, consisting of professional and lay judges. The Supreme Court was authorized to oversee the judicial adjudication in general terms and to issue binding guidelines to the courts. All these structural and operational features have survived to this day. ${ }^{20}$

\section{Limiting Judicial Independence-Then and Now}

The principle of judicial independence was not deeply rooted in the Hungarian legal system. Although some guarantees of the principle appeared in legislation at the end of the 18th century ${ }^{21}$ and the judiciary was institutionally separated from the executive branch during the AustroHungarian Monarchy ${ }^{22}$ for a considerable part of the 20th century, there were various types of authoritarian systems in Hungary, during which, particularly under the two world wars-in

\footnotetext{
${ }^{10}$ Zoltán Fleck, JogsZolgáltató MEChanizmusok aZ ÁllamsZocializmusban [Mechanisms of Administration of Justice In STATE SOCIALISM] 139 (2001).

${ }^{11}$ Magyarország Alaptörvénye [The Fundamental Law of Hungary], Alaptörvény, art. $26, \S 1$.

${ }^{12} 1972$. évi IV (Act IV of 1972) Art. 53, \$1 (Hung.).

${ }^{13}$ Magyarország Alaptörvénye [The Fundamental law of Hungary], Alaptörvény, art. 26, $\$ 2$.

${ }^{14} 1972$. évi IV (Act IV of 1972) art. 51, § 1 (Hung.).

${ }^{15}$ 2011. évi CLXI (Act CLXI of 2011) chs. VI-VII (Hung.).

${ }^{16}$ See supra note 4.

${ }^{17}$ The period of 1956-1988/9 is named after János Kádár, a communist leader and the General Secretary of the Hungarian Socialist Workers' Party from 1956 until his retirement in 1988. Alternatively, some reference 1989, the emblematic year of the collapse of communist rule in Hungary).

${ }^{18}$ ÁdÁm ANTAL, Magyar államjog [Hungarian State Law] 406 (1983); BiHARi OtTó, Államjog [State Law], 330 (1987).

${ }^{19}$ Act IV of 1972, supra note 14 , at arts. 22-25.

${ }^{20}$ This tool has remained until today to guide judicial practice.

${ }^{21} 1790$. évi XII (Act XII of 1790 on some safeguards of judicial independence) (Hung.).

${ }^{22} 1869$. évi IV (Act IV of 1869) (Hung.).
} 
the interwar period and during the decades of socialism - the independence of the judiciary was severely restricted.

Moreover, the history of the administration of justice between 1949 and 1990 can be divided into several stages. The foundations of the judicial system of the communist regime were laid down in 1949-50. ${ }^{23}$ Although the communist Constitution declared that "in the Hungarian People's Republic the judges are independent and subject only to the law," 24 the legal and personal conditions of the proletarian dictatorship were established, and the transformation of the judicial system followed the model of the Stalinist Constitution of 1936 and the Court Act of 1938 of the Soviet Union. In the turbulent years of the post-war period between 1945 and 1949, the war criminals were convicted by politically motivated courts and the first show trials took place. Under the totalitarian era between 1949 and 1953, the use of courts for open political purposes was completed. Whereas during the "new phase" — marking moderate democratization process-which lasted from June 1953 to April 1955, there were some attempts to redress the infringements of the dictatorship within the framework of "socialist legality," after the suppression of the 1956 revolution. Between 1957 and 1962, the courts became again the instruments of repressive actions against the revolutionists. After the consolidation of the Kádár regime, especially as a result of the constitutional amendment of 1972, the judiciary also consolidated, and the judicial independence-within the limits of socialist authoritarianism—-strengthened. In the late 1980s under the circumstances of the increasing economic difficulties, growing social and political tensions and in parallel with the modernization of several branches of law, the courts became more and more independent of control of the communist party.

\section{The Instruments and Procedures of Political Control over Courts During the Late Socialism (1972-1989)}

As far as the tools of political control over courts in the period of late socialism, we can distinguish, on the one hand, between the direct and indirect forms of influence, and, on the other hand, between the formalized and informal control mechanisms, even if there are some overlaps between them. ${ }^{25}$

\section{From Direct Control to Indirect Mechanisms of Influence}

Since the mid-1960s, the Kádár regime consolidated, and the use of the courts for overt political repression would have jeopardized the political legitimacy of the system. In the early 1970s, as a part of the judicial reform, a new act on courts was passed, ${ }^{26}$ although judicial reform lasted until the 1980s. ${ }^{27}$ By abolishing regional courts-whose jurisdiction covered several counties-a threetier court system was created. The most significant change for our topic was that, as far as the political influence over the judiciary is concerned, the emphasis was shifted from influencing individual judicial cases to shaping legal policy, and thereby the principle of judicial independence was not only recognized by the Constitution and the laws, but in most cases was respected.

Although any judicial proceeding against the high officials of the communist party or the Government required the approval of the appropriately high-level party bodies, even in such cases, political influence was usually exercised not through the courts but at earlier stages of the criminal procedure. In other words, those cases in which a person enjoyed immunity on a political basis

\footnotetext{
${ }^{23}$ 1949. évi XI (Act XI of 1949) (Hung.); 1950. évi IV (Act IV of 1950) (Hung.); 1950. évi XLVI (Legislative Act 46 of 1950) (Hung.).

${ }^{24} 1949$. évi 1949 (Act XX of 1949 on the Constitution of the Hungarian People’s Republic), art. $41 \S 1$ (Hung.).

${ }^{25} \mathrm{On}$ the main features of the exercise of judicial power in socialist countries from the perspective of socialist legal science, see Attila Rácz, Courts and Tribunals, A Comparative Study (1980).

${ }^{26} 1972$. évi IV (Act IV of 1972) (Hung.).

${ }^{27} 1975$. évi I (Act I of 1975) (Hung.); Legislative Decree 16 of 1979 (Hung.), Legislative Decree 25 of 1983 (Hung.).
} 
were not allowed to go to a court. ${ }^{28}$ In particular, after these judicial reforms, politically motivated judicial cases where direct external influence could be exerted rarely occurred. The courts adjudicated with "relative independence." 29 This was also helped by the fact that politically sensitive cases were simply not brought to justice but were resolved in other ways. The police or the prosecutor service, for example, were much more suitable for this due to their hierarchical organizational structure.

Still, courts were not completely free from political control, but apart from rare exceptions of primary political cases, they were not subjected to direct political influence. Instead, it was exercised in indirect ways. This practice was openly accepted and justified by the socialist approach of the legal system stating that " $\mathrm{t}]$ he judiciary does not operate in a vacuum, and the judiciary is also part of the state. The courts also contribute to the implementation of the politics of the party and the socialist state expressed by the law." 30 The service of socialist legality needed political loyalty. "The judge's exclusive dependence on the law is in itself a kind of political dependence." 31

It is also worth noting that a local organization of the communist party operated in every court. Nevertheless, because the legal system itself mediated the political will of the state-party, the courts were involved in maintaining socialist authoritarianism in a way that formally preserved their independence in individual cases. This role was facilitated by the bureaucratic nature of the judiciary, which had several different causes. First, the judiciary was not considered to be an independent branch of power in the socialist constitutional theory, where formally the people's representation - the National Assembly_embodied the unity of public power. Then, the legal system was based on the almost exclusive role of statutory law, discouraging the judge-made law. Finally, administrative issues always played a prominent role in the functioning of the courts. $^{32}$ Overall, all the judges were socialized in circumstances where it was natural for them to represent the socialist system of values and work in a bureaucratic order.

Then, " $[\mathrm{t}]$ hrough the personnel policy and the provision of material conditions, the Ministry of Justice have and have had significant tools with which they can play an effective role in deciding on the substance of the application of law." 33 The filling of judicial leadership positions was subject to approval by the competent party organization. It was important, as legal policy expectations were mostly mediated by county - and capital — court presidents as middle-level administrative leaders. In administrative matters, there was a hierarchical relationship between the local court presidents, the county court presidents, and the Minister of Justice. The court presidents had extensive administrative powers at all levels. For example, they allocated the individual cases among the judges, they controlled day-by-day operation of the courts and the judicial panels, and through their necessary approval of promotion, transfer or secondment of the judges, the court presidents significantly influenced the individual career prospects of judges. ${ }^{34}$ It is worth mentioning too that the presidents of the county courts had to report regularly to the competent party committees on the activity of their courts. ${ }^{35}$

\section{Formalized Tools}

Formalized procedures provided legal tools for judicial leadership to keep the adjudication under control. Some of them are normal and are used also in consolidated democracies, where the

\footnotetext{
${ }^{28}$ FLECK, supra note 10, at 134.

${ }^{29} I d$. at 110 .

${ }^{30}$ Rácz Attila, Bíróság [Court], in Állam- És Jogtudományi EnCiklopédia, I [Encyclopedia of Political SCIENCE AND LAW] 431 (Szabó Imre ed., 1980).

${ }^{31}$ FỨRÉSZ KLÁrA, Bífrói FƯGGETLENSÉG [JUdiCIAL INDEPENDENCE] 26-27 (1989).

${ }^{32} I d$. at $127-28$.

${ }^{33}$ Kulcsár Kálmán, A jogszociológia alapjai [The Fundamentals of Sociology of Law] 296 (1976).

${ }^{34}$ FÜRÉSZ, supra note 31 , at 140 .

${ }^{35}$ FLECK, supra note 10, at 141.
} 
judges' accountability is an equally important principle for judiciary. However, the same processes may function in a different way in authoritarian regimes.

One of these institutionalized channels of central control was the key position of the President of the Supreme Court. The President had wide-ranging powers in managing the whole judiciary. They could take over any judicial case from the competent court at any stage of the proceedings and bring it under the jurisdiction of the Supreme Court. Certainly, it was used only exceptionally, but it served as a final solution for critical cases. In addition, they could challenge any final judicial decision. The wide-ranging powers of the President of the Supreme Court did matter because this position was a very high and trusted one which could only be filled by a reliable and loyal cadre. Formally, the President was elected by the one-party National Assembly on the informal selection of party leadership for four, from 1975 for five years. This was really a high-level and politically important position that required the confidence of party leadership. It is shown by the fact that only two persons filled this position between 1968 and $1990 .^{36}$

As it has been said above, judicial administration also provided effective tools for controlling the judiciary. Apart from the President of the Supreme Court, all judges were elected by the Presidium, a collective head of state body of the People's Republic. The central administration of the judiciary was the power and duty of the Minister of Justice. The Minister of Justice made a proposal to the Presidium for the appointment of the new judges and was empowered to assign judges to the courts. The administrative system of judiciary was a strictly centralized system. All court presidents were appointed by the Minister of Justice on the basis of the approval of the competent party organization. For example, the presidents of the county court houses were appointed on the proposal of the county-level party leadership. In other words, the court leadership belonged to the so-called nomenklatura system, a general mechanism in which the high officials of the state were chosen at all levels by communist party bodies operating in parallel level. ${ }^{37}$

\section{Informal Tools}

As to the informal tools of political control, party membership has to be mentioned. Membership of the state-party (Hungarian Socialist Worker's Party) was not compulsory, but in practice, it was indispensable to the judicial career and promotion. A legislative decree permitted the party membership for judges, ${ }^{38}$ which was abolished only in 1989.

Another obligation was rested on law. The preamble of the Court Act of 1972 stated that a judge must uphold "socialist legality" ${ }^{39}$ The personnel policy of judicial administration played a crucial role in selecting the candidates for judges' positions. The nomination was preceded by a selection procedure to assess the professional, political, and moral suitability of the proposed person for the function. In other words, the new judges had been socialized in an ideologically committed, well-disciplined system at a very early point of their carrier, as the minimum age of being elected as a judge was twenty-four years. After the election, the Minister of Justice assigned the judges to the courts and exercised the most important administrative tasks.

But the most direct channel of political influence over courts was the so-called Coordination Committee, which was set up in 1957 and operated until 1988. It was composed of the secretary of the communist party responsible for administrative matters, the Minister of the Interior, the Minister of Justice, the Chief Prosecutor, and the President of the Supreme Court. ${ }^{40}$ As for its

\footnotetext{
${ }^{36}$ Ödön Szakács (1968-1980) and Jenő Szilbereky (1980-1990).

${ }^{37}$ See HusZÁr TiBOr, Az elittöl a nómenklatúráig (Az intézményesített káderpolitika kialakulása Magyarországon 1945 1989) [From the Elite to the Nomenclature (The Development of Institutionalized Cadre Policy in Hungary 1945-1989)] (2007).

${ }^{38} 9 / 1949$. Korm. r. (Governmental Decree no. 9/1949) (Hung.).

${ }^{39} 1972$. (Act I of 1972 on the Courts) (Hung.).

${ }^{40}$ Révész Béla, A pártállami idöszak ismeretlen hatalmi testülete: a Koordinációs Bizottság (1957-1988) [The Unknown Power Body of the Party-State Period: The Coordination Committee (1957-1988)], 76 ACTA UnIVErsitatis SzEGEDIENSIS: ACTA JURIDICA ET POLITICA 387, 387-99 (2014).
} 
functions, just one year after the constitutional amendment and the adoption of the new Court Law, at a meeting of the political committee of the communist party in 1973, the party leader, János Kádár stated that "[a]ny criminal policy matter or specific criminal case on which there is uncertainty or disagreement among the heads of competent organs, must be brought before this Committee." ${ }^{41}$ In fact, the Coordination Committee operated in an informal way; even its existence was proved only long after the regime change.

\section{The Instruments and Procedures of Political Control over Courts Nowadays}

The general elections of 2010 had brought about a landslide victory of the conservative parties that had been in opposition for eight years beforehand, and the new government parties gained a constitution-making parliamentary majority. On this basis, the Government began comprehensive constitutional and legal reforms which have deeply affected the judicial independence. These reforms aimed at achieving personal changes in the judicial corps, as well as establishing a much more centralized system of judicial administration.

\section{Formalized Tools}

The so-called Transition Provisions of the new Constitution, named Fundamental Law, adopted in December 2011, renamed the Supreme Court Kúria, and provided that the mandate of the President of the Supreme Court would terminate upon the entry into force of the Fundamental Law. ${ }^{42}$ As a consequence, the incumbent President's-Mr. András Baka- mandate was abolished about three and a half years before its normal date of expiry. In addition, new criteria were adopted for the election of the President of the Kúria, and according to the criteria, candidates were required to have at least five years' experience as a judge in Hungary. Because Mr. Baka served for the European Court of Human Rights between 1991 and 2008, rather than for a Hungarian court, he was ineligible for the presidency of Kúria.

In parallel with the removal of the President of the Supreme Court, a new act of Parliament ${ }^{43}$ which came into force simultaneously with the Fundamental Law on 1 January 2012-reduced the compulsory retirement age of judges from 70 to 62 ,prescribing that every judge must retire if he or she "has reached the age-limit for retirement applicable to him . . . with the exception of the President of the Kúria." As a result of this law, in 2012, altogether 274 judges, almost ten percent of all serving judges, had to retire. The change affected even more court leaders because most of them came from the older age group of judges.

Although both measures proved to be illegal as either contrary to $\mathrm{EU}^{\mathrm{law}}{ }^{44}$ or unconstitutional, ${ }^{45}$ neither the prematurely dismissed President of the Supreme Court nor the removed judges have been reinstated in their earlier positions.

In 2012, the central administration of courts was transformed introducing an extremely centralized system headed by the President of the National Office for the Judiciary (NOJ) with wide ranging powers. The President is in charge of all tasks and duties of the central administration of courts, apart from the Kúria. However, the President's powers go far beyond the administrative matters. The power of initiating standardization procedure-a proposal to the Kúria to take decisions on legal issues binding on all courts-determining the criteria of performance assessment of judges, defining behavioral rules, and other actions can deeply affect the judges' professional

\footnotetext{
${ }^{41} I d$.

${ }^{42}$ Magyarország Alaptörvénye [The Fundamental Law of Hungary], Alaptörvény.

${ }^{43}$ 2011. évi CLXII (Act CLXII of 2011 on the Legal Status and Remuneration of Judges) (Hung.).

${ }^{44}$ Baka v. Hungary, App. No 20261/12 (2014), https://hudoc.echr.coe.int/eng\#\{\%22fulltext\%22:[\%22\\%22CASE\%20O F\%20BAKA\%20v.\%20HUNGARY $122 \% 22]$,\%22documentcollectionid2\%22:[\%22GRANDCHAMBER\%22,\%22CHAMBER \%22],\%22itemid\%22:[\%22001-163113\%22]\}

${ }^{45}$ Alkotmánybírósaág (AB) [Constitutional Court] July 17, 2012, 33/2012 (Hung.).
} 
activity and can hardly be classified as administrative powers. The importance of this far-reaching competence is enhanced by the length of the President's term of office of nine years, which may be extended indefinitely if the Parliament fails to elect the new President; in which case the incumbent head of the NOJ remains in office until the National Assembly elects its successor.

The powerful position of the President of the NOJ proved to be detrimental to the judicial independence, as this post was a part of a political spoil system under the overwhelming parliamentary majority of the right-wing coalition Government. The government parties elected as the first President Tünde Handó, who is a wife of a founder and leading politician of the major government party Fidesz, József Szájer. In the past years, by often appointing court leaders arbitrarily, she could build up a kind of clientelism within the judiciary. ${ }^{46}$ It can be demonstrated by the humble-sounding letter of gratitude entitled "Presidential Thanksgiving," published by twentyfour court leaders which appeared on the official website of the judiciary. ${ }^{47}$

In addition, the NOJ President's extensive powers became more problematic in recent years, when she refused any control over her leadership. Her activity should have been controlled by the National Judicial Council, a self-governing body of judges. However, more and more conflicts arose between the National Judicial Council and the President of the NOJ since 2018 when the National Judicial Council began to complain about the irregular practice of the NOJ President in deciding the applications for judicial positions including the leading posts of local and regional courts. The National Judicial Council also criticized that the President had ignored the admonitions of the Council which issued for the President's failure to fulfil certain obligations of hers. As a response to these criticisms, the NOJ President tried to block the renewal of the Council, and, because not all alternate members of the National Judicial Council had been elected, she declared the National Judicial Council illegitimate. In any case, the President of the NOJ, neglecting the National Judicial Council's opinions and recommendations, exercised her power without legal supervision for a long time. ${ }^{48}$ The government parties eventually solved this tension with a golden parachute for Tünde Handó., ${ }^{49}$

It is also very instructive to invoke some failed attempts of introducing certain reforms, because these tell us a lot about how the Government thinks about the principle of judicial independence. In 2011, a dubious completion of the new Fundamental Law ${ }^{50}$ authorized the President of the National Office for the Judiciary to transfer judicial cases from the legally competent court to another one-that is to appoint the acting court at his or her discretion-and did not provide any remedy for the concerned person against this. This was a clear violation of the principle of right to legal judge and equality before the law, and, after heavy international criticism, eventually, was invalidated by the Constitutional Court. ${ }^{51}$

\footnotetext{
${ }^{46}$ See Kovács Ágnes, Ki védi meg a magyar bíróságok függetlenségét? Személyzeti politika a központi igazgatásban [Who Will Protect the Independence of the Hungarian Courts? Personnel Policy in the Central Administration], MTA WORKING LAW PAPERS (2019).

${ }^{47}$ They Say Goodbye to Handó Tünde as a Good Cadre in Communism, INDEX (Nov. 29, 2019), https://index.hu/belfold/ 2019/11/29/hando_tunde_birak_birosagok_bucsuztatasa/ (the letter, from which the Hungarian Judicial Association disavowed in a statement, has since been removed from the website).

${ }^{48}$ Zoltán Szente, Subverting Judicial Independence in the New Authoritarian Regimes: Comparing Polish and Hungarian Judicial Reforms, in The Role of Courts in Contemporary Legal Orders, 350-51 (Martin Belov ed., 2019).

${ }^{49}$ In 2019, the National Judicial Council initiated the discharge of Mrs. Handó by Parliament, but the proposal was rejected by the Legislature. However, at the end of the year, before the end of her term of office, Parliament elected her a member of the Constitutional Court.

${ }^{50}$ In parallel with the entry into effect of the Fundamental Law of 2011, a long piece of constitutional legislation ("Transitional Provisions") came into force on January 1, 2012, containing a number of rules completing and exacting the new constitutional text. However, The Constitutional Court invalidated this curious legislation, objecting, among others, to the uncertain constitutional rank of this piece of legislation. See Alkotmánybíróság (AB) [Constitutional Court] Dec. 29, 2012, 45/2012 (Hung.).

${ }^{51}$ Alkotmánybíróság (AB) [Constitutional Court] Dec. 5, 2013, 36/2013 (Hung.).
} 
The latest challenge to the principle of judicial independence was the attempt to separate administrative courts from the uniform system of the judiciary. The critics of the reform claimed that this kind of reorganization of judiciary was unjustified, as administrative proceedings have been properly administered also by ordinary courts, ${ }^{52}$ where the specialization of judges dealing with administrative matters has already been realized. Most criticism supposed that the real reason for restructuring the system of administrative courts was to outsource the politically most sensitive matters - such as freedom of information cases, legal disputes related to political rights, refugees, and elections - to specialized courts under the strong supervision of the Government. These suspicions have been confirmed by the selection method of the administrative judges-preferring those candidates who have professional experience as government officials.

\section{Informal Tools}

The new Constitution contains a number of provisions which are clearly aimed at guiding the functioning of the courts and limiting their interpretative autonomy. The Fundamental Law imposes binding methods of legal interpretation for the courts. Thus,

[i]n the course of the application of law, courts shall interpret the test of the legal regulations primarily in accordance with their purposes and with the Fundamental Law. Primarily, the preamble of the legal regulation, and the reasoning of the legal regulation or its amendment shall be taken into account when the purposes of the legal regulations are established. When interpreting the Fundamental Law or legal regulations, it shall be presumed that they serve moral and economical purposes which are in accordance with common sense and the public good. ${ }^{53}$

Then, the Constitution obliges all public authorities, including courts, to respect the principle of "balanced, transparent and sustainable budget management." " The seventh amendment to the Fundamental Law added to the paragraph quoted above that "[p]rimarily, the preamble of the legal regulation, and the reasoning of the legal regulation or its amendment shall be taken into account when the purposes of the legal regulations are established."

Even though there is no longer a mandatory ideological commitment, such as the protection of social system of socialism, there are still indirect attempts to influence the judges' attitudes and behaviors. If the promotion is influenced also by factors other than professional performance, such as loyalty to the administrative leader or implicit expectations for "good" decisions in sensitive matters, there is a high risk that judges will try to adjust to even the informal expectations. Thus, for instance, the quasi-politicalstatements of judicial leaders or the interruption of relations with civil organizations in accordance with the Government's policy, ${ }^{55}$ may send messages to judges what attitudes are preferred in the whole judiciary. ${ }^{56}$ There are many indications that these informal mechanisms are at work. Since 2010, several well-known judges have resigned due to pressure on the courts or on their own person.

\footnotetext{
${ }^{52}$ See European Commission, EU Justice SCOREboArd, (2021), https://ec.europa.eu/info/policies/justice-andfundamental-rights/effective-justice/eu-justice-scoreboard_en.

${ }^{53}$ Magyarország Alaptörvénye [The Fundamental law of Hungary], Alaptörvény, art. 28.

${ }^{54}$ Magyarország Alaptörvénye [The Fundamental Law of Hungary], Alaptörvény, art. N $\$ \$ 1,3$.

${ }^{55}$ Thus, for example, at the peak of the Government's campaign against the NGOs-among others, stigmatizing many of them as foreign-funded organizations serving the global political ambitions of an American billionaire, George Soros-the NOJ terminated its cooperation with several civil organizations.

${ }^{56}$ In recent years, several judges have justified their departure from the judiciary by referring to such political pressure. See, e.g., https://444.hu/2018/09/13/lemond-szepeshazi-peter-biro-a-hando-fele-igazsagszolgaltatas-egyik-leghangosabbkritikusa; https://www.napi.hu/magyar-gazdasag/tiltakozasbol-lemondott-egy-biro.655151.html; https://merce.hu/2019/02/ 05/a-lemondott-biro-szerint-nyilt-hatalmi-haboru-zajlik-az-igazsagszolgaltatas-ellen-az-ugyeszseg-sertve-erzi-magat/.
} 
However, the most effective way of informally influencing the courts is undoubtedly to capture the judicial leadership by appointing people loyal to the government to the most important judicial posts. The best example of this is the election of Mr. András Varga Zs., the President of the Kúria in the autumn of 2020, although he has never been a judge before. ${ }^{57}$ It is also worth noting that on the recommendation of the new President of the Kúria, the President of the Republic appointed András Patyi, who proved his loyalty to the government as President of the National Election Committee between 2013 and 2018, as Deputy President of the Kúria for a six-year term in spring 2021.

\section{Comparing the Instruments Limiting Judicial Independence in the Past and the Present-Similarities and Differences}

As it can be seen, certain influencing tools and channels exist in both cases. In addition, even if there are differences in the degree of their application and result, it is necessary to emphasize that while the period between 1972 and 1989 was an epoch of a declining authoritarian regime, since 2010 there has been a process towards a semi-authoritarian system moving away more and more from the values and principles of the rule of law.

In any case, the comparison shows that the instruments of judicial administration may be well suited to exercise effective control over courts, particularly through the appointment of court lead$\mathrm{ers}^{58}$ who are loyal to the central leadership. Before the regime change in 1989-90 and after 2010, the centralized system of court administration had great importance in this regard, despite the fact that different models of judicial administration were used. In neither case was direct influence over courts giving direct instructions to them to produce concrete outcome in specific cases. However, administrative dependence can have a significant influence on the independence of adjudication. More and more signs show that the extent of centralization of judicial administration carries more weight than its basic organization character. It seems that, although after 2010 the reform of the judicial administration preserved the principle of judicial self-government, the external pressure on the courts has increased and the independence of the judiciary has been seriously threatened.

There are also many signs - including statements by some resigned judges - that the performance and integrity of the judiciary is threatened by the practice of isolating certain politically sensitive cases from the judiciary, with the formal involvement of the public prosecution service which prevents such cases from being brought to courts. This was also a well-established practice during the socialist period, as it has been described earlier. Notwithstanding, this practice helps to maintain the appearance of judicial independence by preventing courts from making decisions in such cases. Of course, this kind of independence is of dubious value, as it has a too high price, namely that the judiciary does not fully perform its function.

There is also a noticeable similarity with regard to the intentions of orientating the judicial activities. The several provisions of the Fundamental Law restricting the interpretative autonomy of the courts play a role similar to that of the legal policy requirements of late socialism. Both efforts aimed at making the judge only the "mouth" of the law-making will, in other words, to make the application of law as automatic as possible.

Notably, it may be surprising that after 2010, several methods were used which were capable of undermining judicial independence but were unknown in the era of late socialism. The removal of a number of judges and judicial leaders from their office was an unorthodox and harsh attack on

\footnotetext{
${ }^{57}$ This was made possible by an omnibus law in 2019, under which the members of the Constitutional Court are appointed as judges by the President of the Republic at their request. Under this Act, the head of state appointed eight constitutional judges as judges in the summer of 2019 and Varga Zs. was one of them. Zoltán SZENTE, CONSTITUTIONAL LAW IN HungarY 213 (2021).

${ }^{58}$ The possible forms of influence have been addressed, for example, in Adam Blisa \& David Kosař, Court Presidents: The Missing Piece in the Puzzle of Judicial Governance, 19 GERMAN L. J. 2031-75 (2018).
} 
judicial independence-it was unprecedented even in the late Kádár era. It is true however, that this was due to the fact that the purge of the judiciary had taken place well before 1972 . Nevertheless, it is undeniable that the Government today has only more limited instruments to influence the courts than before the regime change. This is shown by the fact that it is much slower process to pack the ordinary courts than to subjugate other public authorities.

However, it cannot be ignored that most of the similarities are not based on some kind of continuity. Certainly, there are traditions, customs, and routines that live on to this day. Judicial corps is still a very closed community, with a conservative spirit, in which the textualist interpretation of law is dominant. But in the case of the other characteristics, they do not come from continuity, but the results of the revival of the influencing practices of the late Kádár era. These features have not been produced by a kind of post-socialist authoritarianism, but they are the outcomes of an emerging semi-authoritarian political regime. Regardless, the attitude and behavioral patterns of the Hungarian judicial corps is well characterized by the fact that the newly applied restrictions of judicial independence did not provoke any significant resistance. A few judges resigned, but there were no such types of protests like in Poland, where after a very similar past very similar trends have taken place. ${ }^{59}$

Yet, there are some lessons to be learned from the past experiences. First, an authoritarian government will always strive to eliminate or at least control autonomous institutions such as the judiciary. Second, formal safeguards are hardly sufficient to maintain judicial independence. The well-established ethos of judges, the culture of judiciary and the commitment in wider social and political context to the judicial independence are all necessary conditions. Finally, taking account also of the experience of the periods before the judicial reform of 1972, it can be concluded that the more extensive an authoritarian system is, the more direct tools and methods it applies for political control of the courts.

${ }^{59}$ See SZENTE, supra note 48.

Cite this article: Szente Z (2021). Stepping Into the Same River Twice? Judicial Independence in Old and New Authoritarianism. German Law Journal 22, 1316-1326. https://doi.org/10.1017/glj.2021.69 